\title{
ASYMPTOTIC ESTIMATE OF A PETROV - GALERKIN METHOD FOR NONLINEAR OPERATOR-DIFFERENTIAL EQUATION
}

\author{
$\boldsymbol{P . V}$. Vinogradova, Far Eastern State Transport University, Khabarovsk, Russian \\ Federation, vpolina17@hotmail.com, \\ A.M. Samusenko, Far Eastern State Transport University, Khabarovsk, Russian \\ Federation, samusenkoalexander@gmail.com, \\ I.S. Manzhula, Far Eastern State Transport University, Khabarovsk, Russian \\ Federation, vm@festu.khv.ru
}

\begin{abstract}
In the current paper, we study a Petrov - Galerkin method for a Cauchy problem for an operator-differential equation with a monotone operator in a separable Hilbert space. The existence and the uniqueness of a strong solution of the Cauchy problem are proved. New asymptotic estimates for the convergence rate of approximate solutions are obtained in uniform topology. The minimal requirements to the operators of the equation were demanded, which guaranteed the convergence of the approximate solutions. There were no assumptions of the structure of the operators. Therefore, the method, specified in this paper, can be applied to a wide class of the parabolic equations as well as to the integraldifferential equations. The initial boundary value problem for nonlinear parabolic equations of the fourth order on space variables was considered as the application.

Keywords: Cauchy problem; operator-differential equation; Petrov - Galerkin method; orthogonal projection; convergence rate.
\end{abstract}

\section{Introduction}

Galerkin methods are widely used in various stages of mathematical modeling. These methods are used for study of the correctness of the mathematical model and the development of the approximate algorithms (see [1,2], etc). One of these methods is the Petrov - Galerkin method. It is based on the use of two basises. The approximate solutions are constructed by the first basis, while the residual must be orthogonal to the second basis (see [3]). Petrov - Galerkin method was used in [4, 5] for the numerical solution of stationary models. This method has been investigated in $[2,6,7]$ for parabolic mathematical models with a dominant convection.

When the two basises are linked through a linear operator, Petrov - Galerkin method is called the moments method. The analysis of the moments method applied to the linear ordinary differential equations was given in [8, 9]. A.V. Dzishkariani [10] used this method in the construction of projection-iterative method for linear elliptic boundary value problems. A.G. Zarubin [11] studied the same method for quasilinear stationary operator equations in Hilbert space. In $[12,13]$ the moments method was used to approximate determination of eigenvalues for various classes of operator equations. In given papers the convergence of approximate solutions was established and the convergence rate was obtained.

The study of nonlinear mathematical models is one of the difficult problems. The investigation of the differential equations in operator form is of special interest. The 
Galerkin method for nonlinear differential-operator equations was studied in [14-16], where eigenvectors of the operator similar to the leading operator $A$ of the equation were used as the basis functions. However, in specific mathematical models it is not always possible to find the explicit form of eigenvectors. In this paper, with the help of the moments method the approximate solution of the Cauchy problem for operator-differential equation is constructed in separable Hilbert space $H$. In contrast to [14-16] here the basis elements are not eigenvectors of a similar operator, which significantly expands the class of problems. In these papers a leading operator $A$ and similar operator $B$ satisfy the acute-angle inequality. In the present paper, this limitation is removed. New asymptotic estimates for the convergence rate of approximate solutions are obtained in uniform topology. The results are illustrated by the initial-boundary value problem for a nonlinear parabolic equation.

\section{Statement of the Problem and Auxiliary Assertions}

Let $H_{1}$ be separable Hilbert space densely and compactly embedded in a separable Hilbert space $H$ with norm $\|\cdot\|_{H} \equiv\|\cdot\|$ and inner product $(\cdot, \cdot)$.

In the space $H$, we consider the Cauchy problem

$$
u^{\prime}(t)+A u(t)+K(u(t))=h(t), \quad u(0)=0,
$$

where $u(t)$ is the unknown function, $h(t)$ is a given function. The functions $u(t)$ and $h(t)$ are determined on $[0, T](T<\infty)$. In the sequel, we assume that the operators $A$ and $K$ satisfy the following conditions:

(i) $A$ is self-adjoint positive definite operator in $H$ with the domain $D(A)=H_{1}$.

(ii) The operator $K$ is subordinate to operator $A$ with order $\alpha$; i.e., $D(K) \supseteq D(A)$ and for any element $v$ from $H_{1}$, the inequality

$$
\|K(v)\| \leq \varphi\left(\left\|A^{1 / 2} v\right\|^{2}\right)\|A v\|^{\alpha}, \quad 0 \leq \alpha<1
$$

holds, were $\varphi(\xi)$ is the nondecreasing continuous positive function on $[0, \infty)$.

(iii) The nonlinear operator $K$ is monotone.

Let us define some spaces that will be necessary further.

Let $L_{2}(0, T ; H)$ be a Hilbert space of all strongly measurable functions on $[0, T]$ with finite norm

$$
\|u\|_{0,2}=\left(\int_{0}^{T}\|u(t)\|^{2} d t\right)^{\frac{1}{2}}
$$

Consider the functions $u(t)(0 \leq t \leq T)$ with values in $H_{1}$ and with norm $\left(\int_{0}^{T}\|A u(t)\|^{2} d t\right)^{\frac{1}{2}}<\infty$. Let the functions $u(t)$ have derivatives $u^{\prime}(t) \in L_{2}(0, T ; H)$ in the sense of distributions. Equip the set of these functions with the norm

$$
\|u\|_{1,2}=\left(\int_{0}^{T}\left(\left\|u^{\prime}(t)\right\|^{2}+\|A u(t)\|^{2}\right) d t\right)^{\frac{1}{2}}
$$

The completion of this set with respect to this norm is a Hilbert space $W_{2}^{1}\left(H, H_{1}\right)$. 
Introduce the subspace $\stackrel{\circ}{W_{2}^{1}}\left(H, H_{1}\right)=\left\{u(t) \in W_{2}^{1}\left(H, H_{1}\right), u(0)=0\right\}$.

The solution of problem (1) is defined as a function $u(t) \in \stackrel{\circ}{W_{2}^{1}}\left(H, H_{1}\right)$ that satisfies (1) for almost all $t$.

Condition (i) implies that the operator $A$ has an inverse $A^{-1}: H \rightarrow H_{1}$.

Futher, the following Bihary result (see [17]) will be necessary for us.

Lemma 1. Let $g(s)$ be a positive function for $s>0$ and let $k, m \geq 0$. Then from the inequality

$$
u(t) \leq k+m \int_{a}^{t} v(s) g(u(s)) d s, \quad a \leq t \leq b
$$

it follows that

$$
u(t) \leq G^{-1}\left(G(k)+m \int_{a}^{t} v(s) d s\right)
$$

where $G(u)=\int_{u_{0}}^{u} \frac{d t}{g(t)}, u>u_{0}>0$.

Theorem 1. Suppose that $h(t) \in L_{2}(0, T ; H)$, the operator $K$ is compact in $L_{2}(0, T ; H)$. Then (1) has a unique solution in $\stackrel{\circ}{W_{2}^{1}}\left(H, H_{1}\right)$.

Proof. It is known (see [18]) that the problem

$$
v^{\prime}(t)+A v(t)=g(t), \quad v(0)=0
$$

with $g(t) \in L_{2}(0, T ; H)$ has a unique solution $v(t) \stackrel{\circ}{W_{2}^{1}}\left(H, H_{1}\right)$; moreover,

$$
\int_{0}^{T}\left(\left\|v^{\prime}(t)\right\|^{2}+\|A v(t)\|^{2}\right) d t \leq M \int_{0}^{T}\|g(t)\|^{2} d t,
$$

where the positive constant $M$ is independent of $t$.

From (3) it follows that the linear operator

$$
\left(\frac{d}{d t}+A\right)^{-1}: L_{2}(0, T ; H) \stackrel{\circ}{W_{2}^{1}}\left(H, H_{1}\right)
$$

exists and it is bounded. Make a replacement $\left(\frac{d}{d t}+A\right) u(t)=v(t)$ in (1). Then we obtain a functional equation

$$
v(t)+K\left(\left(\frac{d}{d t}+A\right)^{-1} v(t)\right)=h(t)
$$

with the compact operator $K\left(\left(\frac{d}{d t}+A\right)^{-1}\right)$ in $L_{2}(0, T ; H)$. We shall use the Leray Schauder principle. Consider the family of equations

$$
u^{\prime}(t)+A u(t)+\lambda K(u(t))=\lambda h(t), \quad u(0)=0, \quad 0 \leq \lambda \leq 1 .
$$


Let $u(\lambda, t)$ be the solution of (4). By $M_{i}$ denote various positive constants independent of $\lambda$ and $t$.

Take the inner product of equation (4) by $A u(\lambda, t)$ and integrate the resulting relation over the interval $[0, t], t \leq T$. By applying inequality (2) and $\varepsilon$-inequality, we come to the estimate

$$
\begin{gathered}
\frac{1}{2}\left\|A^{1 / 2} u(\lambda, t)\right\|^{2}+\int_{0}^{t}\|A u(\lambda, \xi)\|^{2} d \xi \leq \frac{1}{2 \varepsilon}\|h(t)\|_{0,2}^{2}+ \\
\frac{\varepsilon}{2} \int_{0}^{t}\|A u(\lambda, \xi)\|^{2} d \xi+\int_{0}^{t}\|A u(\lambda, \xi)\|^{1+\alpha} \varphi\left(\left\|A^{1 / 2} u(\lambda, \xi)\right\|^{2}\right) d \xi .
\end{gathered}
$$

Using Hölder inequality, we get

$$
\begin{gathered}
\frac{1}{2}\left\|A^{1 / 2} u(\lambda, t)\right\|^{2}+\int_{0}^{t}\|A u(\lambda, \xi)\|^{2} d \xi \leq \\
\frac{1}{2 \varepsilon}\|h(t)\|_{0,2}^{2}+\frac{\varepsilon}{2} \int_{0}^{t}\|A u(\lambda, \xi)\|^{2} d \xi+ \\
\left(\int_{0}^{t}\|A u(\lambda, \xi)\|^{2} d \xi\right)^{\frac{1+\alpha}{2}}\left(\int_{0}^{t} \varphi^{\frac{2}{1-\alpha}}\left(\left\|A^{1 / 2} u(\lambda, \xi)\right\|^{2}\right) d \xi\right)^{\frac{1-\alpha}{2}} .
\end{gathered}
$$

Further, the Young inequality:

$$
a b \leq \frac{1}{\delta} \varepsilon^{\delta} a^{\delta}+\frac{\delta-1}{\delta} \varepsilon^{-\frac{\delta}{\delta-1}} b^{\frac{\delta}{\delta-1}}, a, b, \varepsilon>0, \delta>1
$$

is applied to the right-hand side of the preceding relation. Let $\delta=\frac{2}{\alpha+1}$. Choosing sufficiently small $\varepsilon>0$, we have

$$
\left\|A^{1 / 2} u(\lambda, t)\right\|^{2} \leq M_{1}\left(1+\int_{0}^{t} \varphi^{\frac{2}{1-\alpha}}\left(\left\|A^{1 / 2} u(\lambda, \xi)\right\|^{2}\right) d \xi\right)
$$

By using Lemma 1, we obtain

$$
\sup _{0 \leq t \leq T}\left\|A^{1 / 2} u(\lambda, t)\right\| \leq M_{2}
$$

From (2) and (3) we have

$$
\|u(\lambda, t)\|_{1,2} \leq M_{3}\left(\|h(t)\|_{0,2}+\left(\int_{0}^{T}\|A u(\lambda, t)\|^{2 \alpha} \varphi^{2}\left(\left\|A^{1 / 2} u(\lambda, t)\right\|^{2}\right) d t\right)^{1 / 2}\right) .
$$


By using the last inequality and (5), we get

$$
\|u(\lambda, t)\|_{1,2} \leq M_{4}\left(\|h(t)\|_{0,2}+\left(\int_{0}^{T}\|A u(\lambda, t)\|^{2 \alpha} d t\right)^{1 / 2}\right) .
$$

Since $0 \leq \alpha<1$, then

$$
\|u(\lambda, t)\|_{1,2} \leq M_{5} .
$$

Thus, problem (1), according to the Leray - Schauder principle, has at least one solution $u(t) \in \stackrel{\circ}{W_{2}^{1}}\left(H, H_{1}\right)$. Since the operator $K(\cdot)$ is monotone, the solution is unique. The proof of theorem is complete.

\section{Petrov - Galerkin Method}

Let $\left\{e_{s}\right\}_{s=1}^{\infty}$ be a complete orthogonal system of elements in $H$. The sequence $\varphi_{s} \in H_{1}$ $(s=1,2, \ldots)$ is determined by the equation $A \varphi_{s}=e_{s}$.

Let $P_{n}$ be the orthogonal projection in $H$ onto the linear span $H^{n}$ of the elements $e_{1}, e_{2}, \ldots, e_{n}$.

If $F: H \rightarrow H$ is a linear bounded operator, we have an operator norm

$$
\|F\|_{H \rightarrow H}=\sup _{\|x\|=1}\|F x\|, x \in H .
$$

Let $g(n)=\left\|A^{-1}\left(I-P_{n}\right)\right\|_{H \rightarrow H}$. The operator $A^{-1}$ is compact operator in $H$, therefore, the function $g(n)$ exists, moreover than $g(n) \rightarrow 0$ as $n \rightarrow \infty$. In many cases the function $g(n)$ is accurately calculated or estimated from above by the function which tends to zero as $n \rightarrow \infty$.

The function $g(n)$ is the main characteristics of the convergence rate of approximate solutions found by the moments method. The moments method for the approximate solution of the problem (1) leads to the following equation:

$$
P_{n} u_{n}^{\prime}(t)+A u_{n}(t)+P_{n} K\left(u_{n}(t)\right)=P_{n} h(t), u_{n}(0)=0,
$$

where $u_{n}(t)=\sum_{s=1}^{n} \alpha_{s}(t) \varphi_{s}$.

From now on, by $C$ we denote various positive constants independent of $n$ and $t$.

Lemma 2. Suppose that $h(t) \in L_{2}(0, T ; H)$. Then the inequalities

$$
\begin{gathered}
\sup _{0 \leq t \leq T}\left\|A^{1 / 2} u_{n}\right\| \leq C, \\
\left\|A u_{n}\right\|_{0,2} \leq C
\end{gathered}
$$

hold.

Proof. Let us multiply (6) by $A u_{n}$ in the sense of the inner product in $H$ and then integrate from 0 to $\xi \leq T$. By using the $\varepsilon$-inequality, we come to the relation

$$
\int_{0}^{\xi}\left(P_{n} u_{n}^{\prime}, A u_{n}\right) d t+\int_{0}^{\xi}\left\|A u_{n}\right\|^{2} d t \leq
$$




$$
\frac{1}{2 \varepsilon}\|h\|_{0,2}^{2}+\varepsilon \int_{0}^{\xi}\left\|A u_{n}\right\|^{2} d t+\frac{1}{2 \varepsilon} \int_{0}^{\xi}\left\|K\left(u_{n}\right)\right\|^{2} d t .
$$

Now we transform the first term on the left-hand side of (9):

$$
\int_{0}^{\xi}\left(P_{n} u_{n}^{\prime}, A u_{n}\right) d t=\int_{0}^{\xi}\left(u_{n}^{\prime}, A u_{n}\right) d t
$$

Since $u^{\prime}(t) \in H_{1}$ and condition (i) holds,

$$
\begin{gathered}
\int_{0}^{\xi}\left(P_{n} u_{n}^{\prime}, A u_{n}\right) d t=\int_{0}^{\xi}\left(A^{1 / 2} u_{n}^{\prime}, A^{1 / 2} u_{n}\right) d t=\frac{1}{2} \int_{0}^{\xi} \frac{d}{d t}\left\|A^{1 / 2} u_{n}\right\|^{2} d t= \\
=\frac{1}{2}\left\|A^{1 / 2} u_{n}(\xi)\right\|^{2}-\frac{1}{2}\left\|A^{1 / 2} u_{n}(0)\right\|^{2}=\frac{1}{2}\left\|A^{1 / 2} u_{n}(\xi)\right\|^{2} .
\end{gathered}
$$

By applying (2) to the last term on the right-hand side of (9), using the Young inequality, we obtain

$$
\left\|A^{1 / 2} u_{n}(\xi)\right\|^{2}+\int_{0}^{\xi}\left\|A u_{n}\right\|^{2} d t \leq C\left(\|h\|_{0,2}^{2}+\int_{0}^{\xi} \varphi^{2 /(1-\alpha)}\left(\left\|A^{1 / 2} u_{n}\right\|^{2}\right) d t\right) .
$$

By using Lemma 1, we obtain

$$
\left\|A^{1 / 2} u_{n}(\xi)\right\|^{2} \leq G^{-1}\left(G\left(C\|h(t)\|_{0,2}^{2}\right)+C \int_{0}^{\xi} d t\right)
$$

where $G(z)=\int_{z_{0}}^{z} \frac{d t}{\varphi^{2 /(1-\alpha)}(t)}, z>z_{0}>0$. The existence of the function $G^{-1}(z)$ follows from the positiveness and continuity of the function $\varphi(\xi)$. Thus, estimate (7) is proved. Next, from (10) and (7) we obtain (8). The proof of lemma is complete.

We consider the problem

$$
P_{n} v_{n}^{\prime}(t)+A v_{n}(t)+P_{n} K^{\prime}\left(u_{n}(t)\right) v_{n}(t)=P_{n} h^{\prime}(t), v_{n}(0)=0 .
$$

Lemma 3. Suppose that $h(t) \in L_{2}(0, T ; H), h^{\prime}(t) \in L_{2}(0, T ; H), h(0)=0$ and for any $v \in H_{1}$ the inequality

$$
\left\|K^{\prime}(z(t)) v\right\| \leq \varphi_{1}\left(\left\|A^{1 / 2} z\right\|\right)\|A v\|^{\gamma}\|v\|^{1-\gamma}, \quad 0 \leq \gamma<1
$$

holds, where $K^{\prime}$ is the Fréchet derivative, $\varphi_{1}(\xi)$ is a continuous positive function on $[0 ; \infty)$. Then $v_{n}(t)=u_{n}^{\prime}(t)$.

Proof. Differentiate (6) with respect to $t$. Then

$$
P_{n} u_{n}^{\prime \prime}(t)+A u_{n}^{\prime}(t)+P_{n} K^{\prime}\left(u_{n}(t)\right) u_{n}^{\prime}(t)=P_{n} h^{\prime}(t), u_{n}(0)=0, P_{n} u_{n}^{\prime}(0)=0 .
$$


Take the inner product of the equality $P_{n} u_{n}^{\prime}(0)=0$ by $A u_{n}^{\prime}(0)$

$$
0=\left(P_{n} u_{n}^{\prime}(0), A u_{n}^{\prime}(0)\right)=\left\|A^{1 / 2} u_{n}^{\prime}(0)\right\|^{2} .
$$

Hence,

$$
\left\|u_{n}^{\prime}(0)\right\|=0
$$

From (11) and (13) it follows that

$$
P_{n}\left(v_{n}^{\prime}(t)-u_{n}^{\prime \prime}(t)\right)+A\left(v_{n}(t)-u_{n}^{\prime}(t)\right)+P_{n} K^{\prime}\left(u_{n}(t)\right)\left(v_{n}(t)-u_{n}^{\prime}(t)\right)=0 .
$$

Take the inner product of (14) by $A\left(v_{n}-u_{n}^{\prime}\right)$ and integrate the resulting relation over the interval $[0, \xi], \xi \leq T$. Then

$$
\frac{1}{2}\left\|A^{1 / 2}\left(v_{n}(\xi)-u_{n}^{\prime}(\xi)\right)\right\|^{2}+\int_{0}^{\xi}\left\|A\left(v_{n}-u_{n}^{\prime}\right)\right\|^{2} d t \leq \int_{0}^{\xi}\left\|K^{\prime}\left(u_{n}\right)\left(v_{n}-u_{n}^{\prime}\right)\right\|\left\|A\left(v_{n}-u_{n}^{\prime}\right)\right\| d t .
$$

From this, together with (12) and (7), we have

$$
\begin{gathered}
\frac{1}{2}\left\|A^{1 / 2}\left(v_{n}(\xi)-u_{n}^{\prime}(\xi)\right)\right\|^{2}+\int_{0}^{\xi}\left\|A\left(v_{n}-u_{n}^{\prime}\right)\right\|^{2} d t \leq \\
\leq C \int_{0}^{\xi}\left\|A\left(v_{n}-u_{n}^{\prime}\right)\right\|^{1+\gamma}\left\|v_{n}-u_{n}^{\prime}\right\|^{1-\gamma} d t .
\end{gathered}
$$

By applying the Young inequality, we obtain

$$
\left\|A^{1 / 2}\left(v_{n}(\xi)-u_{n}^{\prime}(\xi)\right)\right\|^{2}+\int_{0}^{\xi}\left\|A\left(v_{n}-u_{n}^{\prime}\right)\right\|^{2} d t \leq C \int_{0}^{\xi}\left\|v_{n}-u_{n}^{\prime}\right\|^{2} d t
$$

By using the fact that $A$ is a positive definite operator, we obtain

$$
\int_{0}^{\xi}\left\|v_{n}-u_{n}^{\prime}\right\|^{2} d t \leq C \int_{0}^{\xi}\left\|A^{1 / 2}\left(v_{n}-u_{n}^{\prime}\right)\right\|^{2} d t
$$

Thus,

$$
\left\|A^{1 / 2}\left(v_{n}(\xi)-u_{n}^{\prime}(\xi)\right)\right\|^{2} \leq C \int_{0}^{\xi}\left\|A^{1 / 2}\left(v_{n}-u_{n}^{\prime}\right)\right\|^{2} d t
$$

Further, using the Gronwall inequality, we obtain $v_{n}(t)=u_{n}^{\prime}(t)$. The proof of lemma is complete.

Lemma 4. Let the assumptions of Lemma 3 hold. Then

$$
\left\|u_{n}^{\prime}\right\|_{0,2} \leq C
$$


Proof. Take the inner product of (11) by $A v_{n}$ and integrate the resulting relation over the interval $[0, \xi], \xi \leq T$. Then

$$
\frac{1}{2}\left\|A^{1 / 2} v_{n}(\xi)\right\|^{2}+\int_{0}^{\xi}\left\|A v_{n}\right\|^{2} d t \leq C\left(\left\|h^{\prime}\right\|_{0,2}^{2}+\int_{0}^{T}\left\|K^{\prime}\left(u_{n}\right) v_{n}\right\|^{2} d t\right) .
$$

From the last inequality, by using (12) and estimates (7) and (8), we obtain

$$
\begin{gathered}
\sup _{0 \leq t \leq T}\left\|A^{1 / 2} v_{n}\right\| \leq C, \\
\left\|A v_{n}\right\|_{0,2} \leq C .
\end{gathered}
$$

Next, using Lemma 3, we obtain (15). The proof of lemma is complete.

Theorem 2. Let the assumptions of Lemma 3 hold. Then

$$
\begin{gathered}
\sup _{0 \leq t \leq T}\left\|u_{n}-u\right\| \leq C g^{1 / 2}(n), \\
\left\|A^{1 / 2}\left(u_{n}-u\right)\right\|_{0,2} \leq C g^{1 / 2}(n) .
\end{gathered}
$$

Proof. For the solutions of problems (1) and (6) we have

$$
\left(u-u_{n}\right)^{\prime}+A\left(u-u_{n}\right)+K(u)-K\left(u_{n}\right)=\left(P_{n}-I\right)\left(u_{n}^{\prime}-h+K\left(u_{n}\right)\right) .
$$

Let us multiply this equation by $u-u_{n}$ in the sense of the inner product in $H$ and then integrate from 0 to $\xi \leq T$. By using the monotonicity of the operator $K$, we come to the relation

$$
\frac{1}{2}\left\|u(\xi)-u_{n}(\xi)\right\|^{2}+\int_{0}^{\xi}\left\|A^{1 / 2}\left(u-u_{n}\right)\right\|^{2} d t \leq \int_{0}^{\xi}\left|\left(\left(P_{n}-I\right)\left(u_{n}^{\prime}-h+K\left(u_{n}\right)\right), u-u_{n}\right)\right| d t .
$$

Since $u-u_{n} \in H_{1}$, we have

$$
\frac{1}{2}\left\|u(\xi)-u_{n}(\xi)\right\|^{2}+\int_{0}^{\xi}\left\|A^{1 / 2}\left(u-u_{n}\right)\right\|^{2} d t \leq \int_{0}^{\xi}\left\|u_{n}^{\prime}-h+K\left(u_{n}\right)\right\|\left\|\left(P_{n}-I\right)\left(u-u_{n}\right)\right\| d t .
$$

Since

$$
\begin{gathered}
\left\|\left(P_{n}-I\right)\left(u-u_{n}\right)\right\|=\left\|\left(P_{n}-I\right) A^{-1 / 2} A^{1 / 2}\left(u-u_{n}\right)\right\|=\left\|\left(P_{n}-I\right) A^{-1 / 2}\right\|_{H \rightarrow H}\left\|A^{1 / 2}\left(u-u_{n}\right)\right\|= \\
=\left\|A^{-1 / 2}\left(P_{n}-I\right)\right\|_{H \rightarrow H}\left\|A^{1 / 2}\left(u-u_{n}\right)\right\| \leq g^{1 / 2}(n)\left\|A^{1 / 2}\left(u-u_{n}\right)\right\|,
\end{gathered}
$$


then

$$
\frac{1}{2}\left\|u(\xi)-u_{n}(\xi)\right\|^{2}+\int_{0}^{\xi}\left\|A^{1 / 2}\left(u-u_{n}\right)\right\|^{2} d t \leq g^{1 / 2}(n) \int_{0}^{\xi}\left\|u_{n}^{\prime}-h+K\left(u_{n}\right)\right\|\left\|A^{1 / 2}\left(u-u_{n}\right)\right\| d t .
$$

Next, applying $\varepsilon$-inequality and choosing sufficiently small $\varepsilon>0$, we come to the inequality

$$
\left\|u(\xi)-u_{n}(\xi)\right\|^{2}+\int_{0}^{T}\left\|A^{1 / 2}\left(u-u_{n}\right)\right\|^{2} d t \leq C\left(\|h\|_{0,2}^{2}+\left\|u_{n}^{\prime}\right\|_{0,2}^{2}+\left\|K\left(u_{n}\right)\right\|_{0,2}^{2}\right) g(n) .
$$

From (2) and (15) we obtain (16) and (17). The proof of the theorem is complete.

\section{Application to Initial-Boundary Value Problems}

In this section, the projection method is applied to a nonlinear parabolic equation with discontinuous boundary conditions.

Let $\bar{\Omega}=[0,1] \times[0,1], \bar{Q}=\bar{\Omega} \times[0, T]$. In $\bar{Q}$, consider the following initial-boundary value problem:

$$
\begin{gathered}
\frac{\partial u\left(x_{1}, x_{2}, t\right)}{\partial t}+\Delta^{2} u\left(x_{1}, x_{2}, t\right)+u\left(x_{1}, x_{2}, t\right)\left|u\left(x_{1}, x_{2}, t\right)\right|^{\rho}=h\left(x_{1}, x_{2}, t\right), \quad\left(x_{1}, x_{2}, t\right) \in Q \\
u\left(x_{1}, x_{2}, 0\right)=0, \quad\left(x_{1}, x_{2}\right) \in \bar{\Omega} \\
\left.u\right|_{\partial \Omega}=0, \frac{\partial u\left(0, x_{2}, t\right)}{\partial \nu}=\frac{\partial u\left(1, x_{2}, t\right)}{\partial \nu}=\frac{\partial^{2} u\left(x_{1}, 0, t\right)}{\partial \nu^{2}}=\frac{\partial^{2} u\left(x_{1}, 1, t\right)}{\partial \nu^{2}}=0,
\end{gathered}
$$

where $\rho \geq 1, \nu$ is external normal to $\partial \Omega$.

Let $H=L_{2}(\Omega), H_{1}=\stackrel{\circ}{W_{2}^{4}}(\Omega)$, where $\stackrel{\circ}{W_{2}^{4}}(\Omega)=\left\{v\left(x_{1}, x_{2}\right) \in W_{2}^{4}(\Omega),\left.v\left(x_{1}, x_{2}\right)\right|_{\partial \Omega}=\right.$ $\left.0, \frac{\partial v\left(0, x_{2}\right)}{\partial \nu}=\frac{\partial v\left(1, x_{2}\right)}{\partial \nu}=\frac{\partial^{2} v\left(x_{1}, 0\right)}{\partial \nu^{2}}=\frac{\partial^{2} v\left(x_{1}, 1\right)}{\partial \nu^{2}}=0\right\}, W_{2}^{4}(\Omega)$ is the Sobolev space (see [19]).

On $H_{1}$ define the operators $A=\Delta^{2}$ and $K=(I \cdot)|I \cdot|^{\rho}$.

It is known that the system of the functions $e_{k j}\left(x_{1}, x_{2}\right)=\sin k \pi x_{1} \sin j \pi x_{2}, \quad(k=$ $1,2, \ldots, j=1,2, \ldots)$ is a complete orthogonal system in $L_{2}(\Omega)$. Let $P_{n}$ be the orthogonal projection in $L_{2}(\Omega)$ onto the linear span $H^{n}$ of the functions $\left\{e_{k j}\left(x_{1}, x_{2}\right)\right\}_{k, j=1}^{n}$.

The functions $\varphi_{k j}\left(x_{1}, x_{2}\right) \in \stackrel{\circ}{W_{2}^{4}}(\Omega)$ are the solution of the equation

$$
\Delta^{2} \varphi_{k j}\left(x_{1}, x_{2}\right)=e_{k j}\left(x_{1}, x_{2}\right)
$$

From the form of functions $\varphi_{k j}\left(x_{1}, x_{2}\right)$, we obtain

$$
g(n)=\left\|\left(\Delta^{2}\right)^{-1}\left(I-P_{n}\right)\right\|_{L_{2}(\Omega) \rightarrow L_{2}(\Omega)} \leq \frac{C}{n^{3}} .
$$

The approximate solution for (18) - (20) is defined as

$$
u_{n}\left(x_{1}, x_{2}, t\right)=\sum_{k, j=1}^{n} a_{k j}(t) \varphi_{k j}\left(x_{1}, x_{2}\right),
$$


where the unknown functions $a_{k j}(t)$ are the exact solution of the Cauchy problem

$$
P_{n} u_{n}^{\prime}+\Delta^{2} u_{n}+P_{n} u_{n}\left|u_{n}\right|^{\rho}=P_{n} h, u_{n}\left(x_{1}, x_{2}, 0\right)=0 .
$$

Let us check inequality (2).

By using the embedding of the space $W_{2}^{4}(\Omega)$ into $C^{2}(\bar{\Omega})$, we obtain

$$
\|K(v)\|_{L_{2}(\Omega)}=\left\|v|v|^{\rho}\right\|_{L_{2}(\Omega)} \leq C\|v\|_{C(\Omega)}^{\rho+1} .
$$

Since

$$
\|v\|_{C(\Omega)} \leq C\|v\|_{W_{2}^{2}(\Omega)}, \quad\|v\|_{C(\Omega)} \leq C\|\Delta v\|_{L_{2}(\Omega)}=C\left\|A^{1 / 2} v\right\|_{L_{2}(\Omega)} .
$$

From (22) it follows that

$$
\left\|v|v|^{\rho}\right\|_{L_{2}(\Omega)} \leq C\left\|A^{1 / 2} v\right\|_{L_{2}(\Omega)}^{\rho+1}
$$

Thus, (2) holds if $\alpha=0$.

Let us check inequality (12). Write down the Fréchet derivative of the operator $K$ :

$$
K^{\prime}\left(z\left(x_{1}, x_{2}, t\right)\right) v\left(x_{1}, x_{2}\right)=(1+\rho)\left|z\left(x_{1}, x_{2}, t\right)\right|^{\rho} v\left(x_{1}, x_{2}\right) .
$$

Next,

$$
\left\|K^{\prime}(z) v\right\|_{L_{2}(\Omega)} \leq(1+\rho)\|z\|_{C(\bar{\Omega})}^{\rho}\|v\|_{L_{2}(\Omega)} \leq C\|\Delta z\|_{L_{2}(\Omega)}^{\rho}\|v\|_{L_{2}(\Omega)} .
$$

Hence, (12) holds if $\gamma=0$.

Let $h\left(x_{1}, x_{2}, t\right) \in L_{2}(Q)$ and $h\left(x_{1}, x_{2}, 0\right)=0$. Then from Theorem 2 it follows that

$$
\begin{gathered}
\sup _{0 \leq t \leq T}\left\|u_{n}\left(x_{1}, x_{2}, t\right)-u\left(x_{1}, x_{2}, t\right)\right\|_{L_{2}(\Omega)} \leq C n^{-3 / 2}, \\
\left\|\Delta\left(u_{n}\left(x_{1}, x_{2}, t\right)-u\left(x_{1}, x_{2}, t\right)\right)\right\|_{L_{2}(Q)} \leq C n^{-3 / 2} .
\end{gathered}
$$

The numerical realization of the Petrov - Galerkin method for (18) - (20) is made using the Matlab software package. The implementation of this algorithm in the form of a computer program allows to verify (22). The input data for the program are: the function $f\left(x_{1}, x_{2}, t\right)$ and the value of $\rho$. For testing of the algorithm, we put $\rho=1$, $T=1$. We choose $h\left(x_{1}, x_{2}, t\right)$ so that the exact solution of $(18)-(20)$ is $u\left(x_{1}, x_{2}, t\right)=$ $t^{2}\left(x_{1}^{2}-x_{1}\right)^{3}\left(x_{2}^{2}-x_{2}\right)^{3}$. The program finds an approximate solution and compares it with the known exact solution. Table 1 presents the results of numerical experiments containing $\sup _{0 \leq t \leq T}\left\|u_{n}\left(x_{1}, x_{2}, t\right)-u\left(x_{1}, x_{2}, t\right)\right\|_{L_{2}(\Omega)}$ for different values of $n$. The results of numerical $0 \leq t \leq T$. experiments are consistent with the theoretical estimate.

Table

\begin{tabular}{|l|l|l|l|l|l|}
\hline$n=10$ & $n=15$ & $n=20$ & $n=25$ & $n=30$ & $n=35$ \\
\hline $0,253 \cdot 10^{-6}$ & $0,153 \cdot 10^{-7}$ & $0,107 \cdot 10^{-7}$ & $0,793 \cdot 10^{-8}$ & $0,511 \cdot 10^{-8}$ & $0,411 \cdot 10^{-8}$ \\
\hline
\end{tabular}

\section{References}

1. Egorov I.E., Tikhonova I.M. About Convergence Speed of the Stationary Galerkin Method for the Mixed type. Bulletin of the South Ural State University. Series: Mathematical Modelling, Programming and Computer Software, 2012, no. 40 (299), pp. 53-58. 
2. Fedotov E.M. Limit Galerkin - Petrov Schemes for a Nonlinear ConvectionDiffusion Equation. Differential equations, 2010, vol. 46, no. 7, pp. 1042-1052. DOI: $10.1134 / \mathrm{S} 0012266110070116$

3. Petrov G.I. Application of the Galerkin Method to the Problem of the Stability of Viscous Fluid. Journal of Applied Mathematics and Mechanics, 1940, vol. 4, pp. 1-13.

4. Bialecki B., Ganesh M., Mustapha K. A Petrov - Galerkin Method with Quadrature for Elliptic Boundary Value Problems. IMA Journal of Numerical Analysis, 2004, vol. 24, pp. 157-177. DOI: 10.1093/imanum/24.1.157

5. Lin H., Atluri S.N. Meshless Local Petrov - Galerkin (MLPG) Method for ConvectionDiffusion Problems. Computer Modeling in Engineering and Sciences, 2000, vol. 1, no. 2, pp. $45-60$.

6. Demkowicz L., Oden J.T. An Adaptive Characteristic Petrov - Galerkin Finite Rlement Method for Convection-Dominated Linear and Nonlinear Parabolic Problems in One Space Variable. Journal of Computational Physics, 1986, vol. 67, pp. 188-213. DOI: 10.1016/00219991(86)90121-X

7. Demkowicz L., Oden J.T. An Adaptive Characteristic Petrov - Galerkin Finite Element Method for Convection-Dominated Linear and Nonlinear Parabolic Problems Two Space Variable. Computer Methods in Applied Mechanics and Engineering, 1986, vol. 55, pp. 63-87. DOI: $10.1016 / 0045-7825(86) 90086-1$

8. Daugavet I.K. On the Method of Moments for Ordinary Differential Equations. Siberian Mathematical Journal, 1965, vol. 6, no. 1, pp. 70-85.

9. Vainikko G.M. Speed of Convergence of the Method of Moments for Ordinary Differential Equations. Siberian Mathematical Journal, 1968, vol. 9, no. 1, pp. 15-20. DOI: $10.1007 / \mathrm{BF} 02196651$

10. Dzishkariani A.V. The Galerkin - Petrov Method with Iterations. Computational Mathematics and Mathematical Physics, 2003, vol. 43, no. 9, pp. 1260-1269.

11. Zarubin A.G. The Method of Moments for a Class of Nonlinear Equations. Siberian Mathematical Journal, 1978, vol. 19, no. 3, pp. 405-412. DOI: 10.1007/BF01875291

12. Zarubin A.G. On the Rate of Convergence of Projection Methods in the Eigenvalue Problems. Computational Mathematics and Mathematical Physics, 1982, vol. 22, no. 6, pp. 26-35. DOI: 10.1016/0041-5553(82)90093-3

13. Zarubin A.G. The Rate of Convergence of Projection Methods in the Eigenvalue Problem for Equations of Special Form. Computational Mathematics and Mathematical Physics, 1985, vol. 25 , no. 4, pp. 1-7. DOI: 10.1016/0041-5553(85)90133-8

14. Vinogradova P.V., Zarubin A.G. Error Estimates for the Galerkin Method as Applied to Time-Dependent Equations. Computational Mathematics and Mathematical Physics, 2009, vol. 49, no. 9, pp. 1567-1575. DOI: 10.1134/S0965542509090115

15. Vinogradova P. Convergence Rate of Galerkin Method for a Certain Class of Nonlinear Operator-Differential Equation. Numerical Functional Analysis and Optimization, 2010, vol. 31, no. 3, pp. 339-365. DOI: 10.1080/01630561003757728

16. Vinogradova P.V. Galerkin Method for a Nonstationary Equation with a Monotone Operator. Differential Equations. 2010, vol. 46, no. 7, pp. 962-972. DOI: 10.1134/S0012266110070049

17. Beckenbach F., Bellman R. Inequalities. Berlin, Springer, 1961. DOI: 10.1007/978-3-64264971-4

18. Lions J.L., Magenes E. Problémes aux Limites non Homogénes et Applications. V. 1, 2. Paris, Dunod, 1968. 
19. Ladyzhenskaya O.A., Ural'tseva N.N. Linear and Quasilinear Equations of Ellipti Type. N.Y., Academic Press, 1968.

\title{
АСИМПТОТИЧЕСКАЯ ОЦЕНКА МЕТОДА ПЕТРОВА - ГАЛЕРКИНА ДЛЯ НЕЛИНЕЙНОГО ДИФФЕРЕНЦИАЛЬНО-ОПЕРАТОРНОГО УРАВНЕНИЯ
}

\author{
П.В. Виноградова, А.М. Самусенко, И.С. Манжула
}

\begin{abstract}
В работе исследуется метод Петрова - Галеркина для задачи Коши для дифференциально-операторного уравнения с монотонным оператором в сепарабельном гильбертовом пространстве. Доказано существование и единственность сильного решения исследуемой задачи. Получены новые асимптотические оценки скорости сходимости построенных приближенных решений к точному решению в равномерной топологии. На операторы уравнения накладываются минимальные требования, необходимые для сходимости построенных приближенных решений. Отсутствуют какие-либо предположения о структуре операторов. Таким образом, метод исследуемый в данной работе, может быть применен к широкому классу параболических уравнений, а также, интегро-дифференциальных уравнений. В качестве приложения, исследуемый в работе метод, применяется к модельному параболическому уравнению четвертого порядка по пространственным переменным.

Ключевые слова: задача Коши; дифференциально-операторное уравнение; метод Петрова - Галеркина; оператор ортогонального проектирования; скорость сходимоcmu.
\end{abstract}

\section{Литература}

1. Егоров, И.Е. О скорости сходимости стационарного метода Галеркина для уравнения смешанного типа / И.Е. Егоров, И.М. Тихонова // Вестник ЮУрГУ. Серия: Математическое моделирование и программирование. - 2012. - № 40 (299), вып. 14. - С. 53-58.

2. Федотов, Е.М. Предельные схемы Галеркина - Петрова для нелинейного уравнения конвекции-диффузии / Е.М. Федотов // Дифференциальные уравнения. - 2010. - Т. 46, № 7. - C. 1033-1043.

3. Петров, Г.И. Применение метода Галеркина к задаче об устойчивости течения вязкой жидкости / Г.И. Петров // Прикладная математика и механика. - 1940. - Т. 4. - С. 1-13.

4. Bialecki, B. A Petrov - Galerkin Method with Quadrature for Elliptic Boundary Value Problems / B. Bialecki, M. Ganesh, K. Mustapha // IMA Journal of Numerical Analysis. 2004. - V. 24. - P. 157-177.

5. Lin, H. Meshless Local Petrov - Galerkin (MLPG) Method for Convection-Diffusion Problems / H. Lin, S.N. Atluri // Computer Modeling in Engineering and Sciences. - 2000. - V. 1, № 2. - P. $45-60$.

6. Demkowicz, L. An Adaptive Characteristic Petrov - Galerkin Finite Rlement Method for Convection-Dominated Linear and Nonlinear Parabolic Problems in One Space Variable / L. Demkowicz, J.T. Oden // Journal of Computational Physics. - 1986. - V. 67. - P. 188-213. 
7. Demkowicz, L. An Adaptive Characteristic Petrov - Galerkin Finite Element Method for Convection-Dominated Linear and Nonlinear Parabolic Problems Two Space Variable / L. Demkowicz, J.T. Oden // Computer Methods in Applied Mechanics and Engineering. 1986. - V. 55. - P. 63-87.

8. Даугавет, И.К. О методе моментов для обыкновенных дифференциальных уравнений / И.К. Даугавет // Сибирский математический журнал. - 1965. - Т. 6, № 1. - С. 70-85.

9. Вайникко, Г.М. О быстроте сходимости метода моментов для обыкновенных дифференциальных уравнений / Г.М. Вайникко // Сибирский математический журнал. - 1968. T. 9, № 1. - С. 21-28.

10. Джишкариани, А.В. Метод Галеркина - Петрова с итерациями / А.В. Джишкариани // Журнал вычислительной математики и математической физики. - 2003. - V. 43, № 9. C. $1313-1322$.

11. Зарубин, А.Г. О методе моментов для одного класса нелинейных уравнений / А.Г. Зарубин // Сибирский математический журнал. - 1978. - Т. 19, № 3. - С. 575-586.

12. Зарубин, А.Г. О скорости сходимости проекционных методов в проблеме собственных значений / А.Г. Зарубин // Журнал вычислительной математики и математической физики. - 1982. - Т. 22, № 6. - С. 1308-1315.

13. Зарубин, А.Г. О быстроте сходимости проекционных методов в проблеме собственных значений для уравнений специального вида / А.Г. Зарубин // Журнал вычислительной математики и математической физики. - 1985. - Т. 25, № 7. - С. 963-972.

14. Виноградова, П.В. Оценка погрешности метода Галеркина для нестационарных уравнений / П.В. Виноградова, А.Г. Зарубин // Журнал вычислительной математики и математической физики. - 2009. - Т. 49, № 9. - С. 1643-1651.

15. Vinogradova, P. Convergence Rate of Galerkin Method for a Certain Class of Nonlinear Operator-Differential Equation / P. Vinogradova // Numerical Functional Analysis and Optimization. - 2010. - V. 31, № 3. - P. 339-365.

16. Виноградова, П.В. Метод Галеркина для нестационарного уравнения с монотонным оператором / П.В. Виноградова // Дифференциальные уравнения. - 2010. - Т. 46, № 7. C. $955-965$.

17. Беккенбах, Э. Неравенства / Э. Беккенбах, Р. Беллман. - М.: Мир, 1965.

18. Lions, J.L. Problémes aux Limites non Homogénes et Applications. V. 1, 2 / J.L. Lions, E. Magenes. - Paris: Dunod, 1968.

19. Ладыженская, О.А. Линейные и квазилинейные уравнения эллиптического типа / О.А. Ладыженская, Н.Н. Уральцева. - М.: Наука, 1964.

Полина Витальевна Виноградова, доктор физико-математических наук, доцент, кафедра «Высшая математика», Дальневосточный государственный университет путей сообщения (г. Хабаровск, Российская Федерация), vpolina17@hotmail.com.

Александр Маркович Самусенко, кандидат физико-математических наук, доцент, кафедра «Высшая математика», Дальневосточный государственный университет путей сообщения (г. Хабаровск, Российская Федерация), samusenkoalexander@gmail.com.

Илья Сергеевич Манжула, магистрант, кафедра «Высшая математика», Дальневосточный государственный университет путей сообщения (г. Хабаровск, Российская Федерация), vm@festu.khv.ru.

Поступила в редакиию 4 июня 2016 г. 